\title{
Hermeneutics and principles of quality in urban morphology
}

\author{
Javier Poyatos Sebastián, José Luis Baró Zarzo \\ Departamento de Composición Arquitectónica. Universitat Politècnica de València. Valencia, Spain \\ E-mail: jpoyatos@cpa.upv.es, jobazar@cpa.upv.es
}

\begin{abstract}
It is common to ascertain the loss of quality in the urban form during the 20th and 21st centuries, especially in the current globalization scenario, and in comparison to the previous centuries. Relevant authors of the cultural and artistic critique such as Erwin Panofsky, Ernst Gombrich or Enrique Lafuente Ferrari have defended the identification of the quality in the works of creation as the fundamental objective of the critique. Due to this, the research and identification of the quality features in the urban form are pertinent in order to have useful instruments to correct this contemporary cultural loss. It is therefore proposed the identification of quality principles of urban form from a hermeneutic point of view. That is to say, each of these principles as capable of opening a certain horizon of comprehension of a specific perspective of quality. For example, we can aim at: beauty, scale, amenity, grace, order, etc. Each principle, offers then a horizon of understanding and also of urban creativity that assembles into this work from the analysis of operative subprinciples and their verification on specific expressive cases of urban form, in both, historical and current aspects. The principles in turn can intertwine offering cumulative and transverse quality options. Therefore, what is sought, is to offer a pertinent and structured hermeneutical tool for the analysis of urban form in its values of quality and excellence.
\end{abstract}

Keywords: hermeneutics, principles of quality, urban form.

\section{Introduction}

It is common to ascertain the loss of quality in the urban form during the 20th and 21 st centuries, especially in the current globalization scenario, and in comparison to the previous centuries. On the contrary, in the historical city, especially in the heritage city, we can frequently appreciate a noticeable quality in the urban form. Rudolf Arnheim has eloquently written about this current situation: "We observe unmistakable signs of weariness, lack of discipline and responsibility. The design of many buildings, furniture and garments is an example of this decadence. The most disgusting symptoms are translated into an extravagance without limits, vulgar tastes and to trivial thoughts. We are too prone to accept little and to abandon the definitive effort, without taking advantage of all the resources, and to ignore what it used to be the condition sine qua non for worthy art. This insufficiency is reflected in the low quality of most of the works and in the lack of valid criteria for their approval in the mass media" (Arnheim 2001, p. 10). We want to underline the absence of criteria.

On the contrary, the accuracy of the quality values is the role of the architectural and urban criticism in their respective areas. The eminent Spanish theorist and art historian Enrique Lafuente Ferrari $(1985$, p. 26) said: "In general terms, criticism is a subtle and mysterious ability to perceive the most intimate and valuable qualities in things, people or artworks.

These qualities sometimes appear and sometimes even hide within a whirlpool of secondary and superfluous flaws. This perception of quality, this distinction between the secondary and the essential, is for me the most eminent critical ability, and indeed it is not only carried out for works of art.” 


\section{Methodology}

The quality of urban form that in the past was developed from a sort of good sense and collective taste and was slowly and deliberately preserved, must be nowadays achieved in a conscious and polite way. The collective taste in urban form is not the same anymore due to lack of sensitivity, an accelerated pace in the urban transformations, usually giving priority to economic profit, etc. We must then develop a disciplinary education in the matter.

Therefore, the research and identification of the quality features in the urban form is relevant in order to dispose of the corrective tools in the face of this contemporary cultural loss. For this reason the identification of these quality parameters from a hermeneutic point of view is proposed, that is, principles capable of opening a certain horizon of understanding and enjoyment of a specific quality perspective and also a horizon of conscious creation.

It is here understood that the quality in urban form is always connected to the user and the urban life. Form has quality only when it is valuable functionally and aesthetically according to the integrated experience of the user.

Firstly, as we said, it is necessary to pay attention to the splendid achievements in urban form reached in the past, analyzing the diverse principles which originated that quality. It is in this way that we will understand and value better the city of the past. The history of the architectural theory can help us in this sense, by means of the principles that appear in many treatises and essays. These principles are cornerstones for a good practice and have greatly influenced the practice of architecture and urbanism during these historical periods. It is in this way that principles such as beauty, decorum, grace, ornament, taste, etc. appear. Then, it is possible to look into the treatises by Vitruvius, Alberti or Palladio, but also into the essays of the XVIIIth and XIXth centuries. In that way, we'll be conceptually improving our critical vision of the past.

Both the urban form of the past and the historical treatises and essays present a combination of very valuable principles that should be enlarged with other contemporary principles of quality extracted from the phenomenological and psychic experience of the city.

If we go in depth into the analysis and meditation, as Ortega y Gasset (2012) said, of those quality principles in urban form (beauty, elegance, decorum, etc.) we can deduce that they also open other several diverse ways in the process of obtaining quality. We can call them subprinciples of quality. For instance, beauty does not appear isolated; on the contrary, it offers a wide range of distinguishable options such as harmony, elegance, delicacy, refinement, technical perfection, etc. Therefore each of these aspects constitutes a subprinciple of beauty.

Now we are going to provide two testimonies that back and support the necessity of a qualitative deepening in the direction that we are developing. On the one hand, Rudolf Arnheim (2001, p. 11) states: "the qualities that convey human values can be described with considerable accuracy, but many of these descriptions cannot be quantitatively verified by means of measurement or recounting of data. They share this trait with many other facts of the spirit and nature, and it doesn't prevent them from existing or being important".

For his part, Ernst Gombrich (2004, p. 190) confirms this idea: "....and this is what critics did in the ancient times, and what they have been doing ever since, that is, to analyze and to subdivide areas for its admiration, and to articulate the multiplicity of human experience within the canon".

The comprehension of quality principles and subprinciples of urban form is even more needed in order to verify real historical or current cases of urban excellence. It is necessary to study specific urban examples that show an evident quality in the form. It is possible in this way to create a catalogue of typological concretions of form, supported with cases, from the quality principles and subprinciples that have been analyzed.

Besides a better understanding and valuation of the city of the past and that of today, such a critical profile of the principles of excellence can contribute to overcome the poorness of form in the contemporary city, with new project conceptual resources. In this way, each 
principle offers a horizon of understanding and also of urban creativity.

The principles and subprinciples in turn can intertwine offering cumulative and transverse quality options. Therefore, what this work expects is to offer a pertinent and structured hermeneutical tool for the analysis of urban form in its values of quality and excellence.

Such way of acting is related to classical research in urban form. An example of this is the one carried out by Gordon Cullen in The Concise Townscape (2001) or that of Christopher Alexander in A Pattern Language (1980).

These studies try to determine certain principles or concepts of form and their clarifying with examples. The difference with these works that are more general is that in here the goal of these principles is to grasp directly and specifically the quality hints of urban form quality.

The principles or concepts are in turn ideal to be used as keywords to consciously channel creativity in urban design.

\section{Measurement and analysis}

Principles

Without an intention of thoroughness and offering evidence to the critical contrast with other possible interested authors, we initially expose six quality principles of urban form

Figure 1.

Place Vendôme,

Paris, by Jules H a r d o u i n Mansart. Example of the principle of beauty.

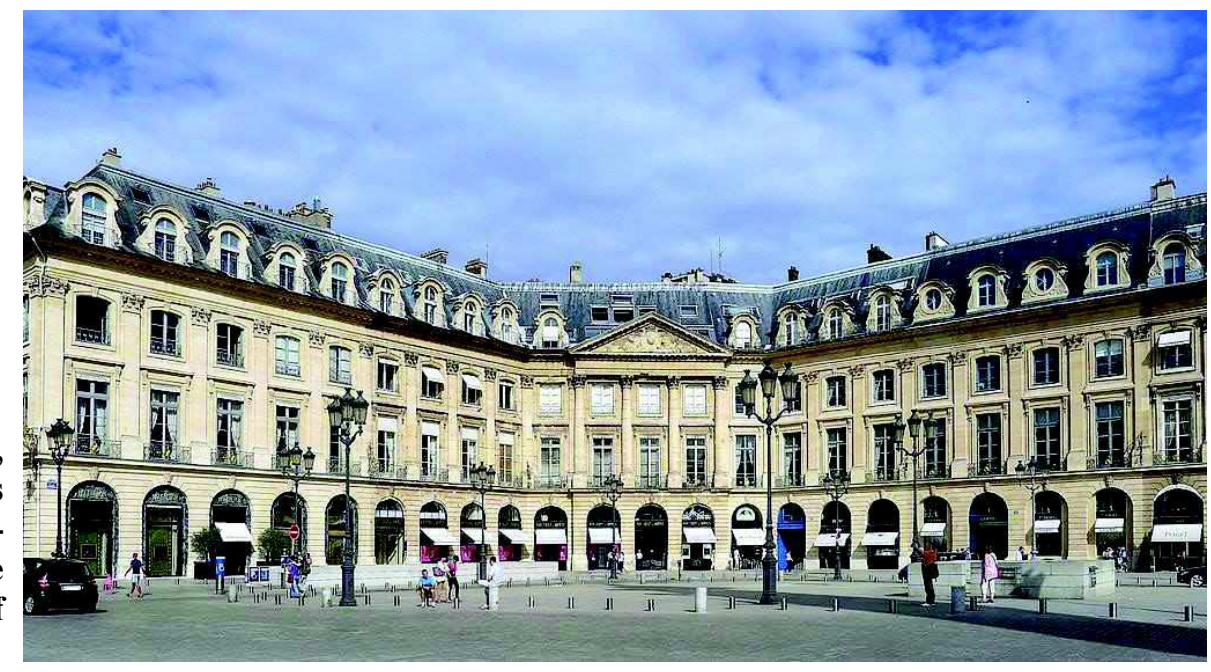

Figure 2.

Kiefhoek quarter,

$R$ o t $t$ e $r$ d a $m$, by J.J.P. Oud. Example of the principle of scale.

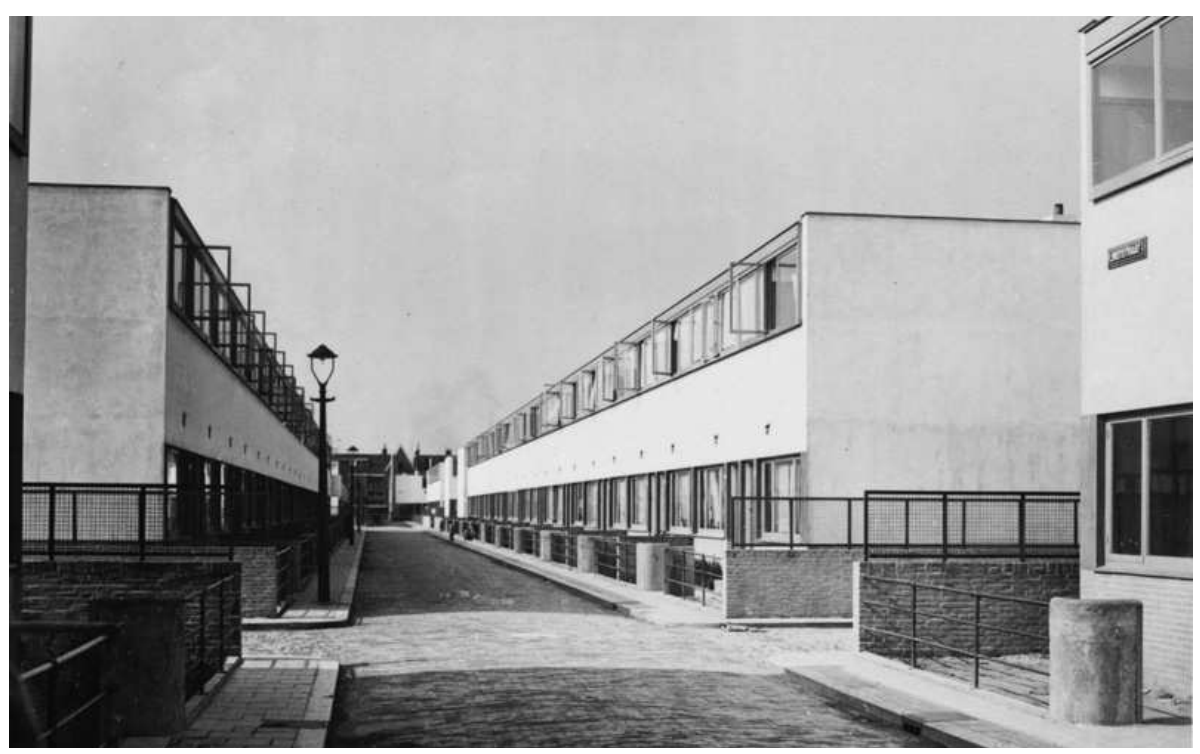


together with a real expressive case of city. Each principle contributes with a type of value that is beneficial in terms of form.

\section{Beauty (Figure 1)}

Taking advantage of Thomas Aquinas definition, pulchrum est quod visum placet, we will define beauty as that which is pleasant to the spirit contemplation. Philosophy and aesthetics authors have witnessed many variants of beauty -or subprinciples, as we have called them here-The aesthetics expert Tatarkiewicz says: "there have been many attempts of classifying these varieties of beauty. A list of exceptional perfection can be found in the work of Goethe. Among these varieties he names the following ones: depth, invention, expressiveness of form, sublimity, individuality, spirituality, nobility, sensitivity, good taste, aptitude, convenience, power, elegance, courtesy, plenitude, wealth, zeal, charm, grace, glamour, skill, brightness, vitality, gentleness, splendour, sophistication, style, rhythm, harmony, pureness, correctness, and perfection. Although it is a long list, it is not as thorough as it should be, and it does

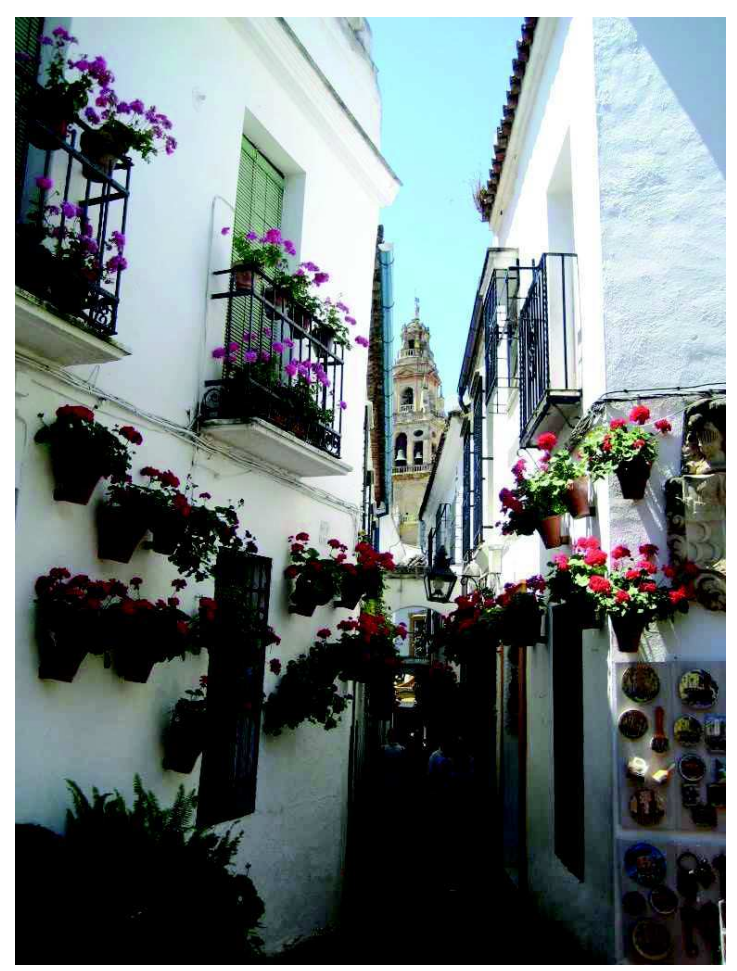

Figure 3.

Streets in Córdoba, Spain. Example of the principle of grace. not take into consideration aspects such as dignity, magnificence, exuberance, poetry and naturalness" (TATARKIEWICZ 2007, p. 186).

\section{Scale (Figure 2)}

It is the right size of the urban form in relation to the inhabitants or users, in such a way that it generates in them a sensation of functional and psychological comfort. Therefore, if they have the right scale, buildings and urban spaces could contribute to a sensation of welcome and empathy for the citizens.

\section{Grace (Figure 3)}

It constitutes the kind and friendly aspect of the urban form.

\section{Amusement (Figure 4)}

It constitutes the manifold and stimulating aspect of the urban form.

\section{Decorum (Figure 5)}

It is the way in which urban form is adapted to different purposes and social meanings.

\section{Identity (Figure 6)}

It is the coherence between urban form and the identity values of the community that embraces it.

\section{Subprinciples}

Now we are going to address the subprinciples of beauty in the urban form, that is, the multiple varieties of beauty present in the urban form. The principle of beauty is the one that possesses the biggest amount and diversity of subprinciples. It is for this reason that we will study it in detail and with special dedication in this work. Beauty, understood as the quality that pleases the citizen's spirit, is the most outstanding quality principle, and consequently it requires a preferential attention due to its richness; this attention corresponds to the one that beauty has received through history. Some relevant subprinciples of beauty are going to be explained now in a general way:

\section{Harmony in buildings}

Here we refer to a classical expression of beauty. When the diverse is in many cases based on 
Figure 4.

Urban Landscape of Amsterdam city. Example of the principle of amusing.

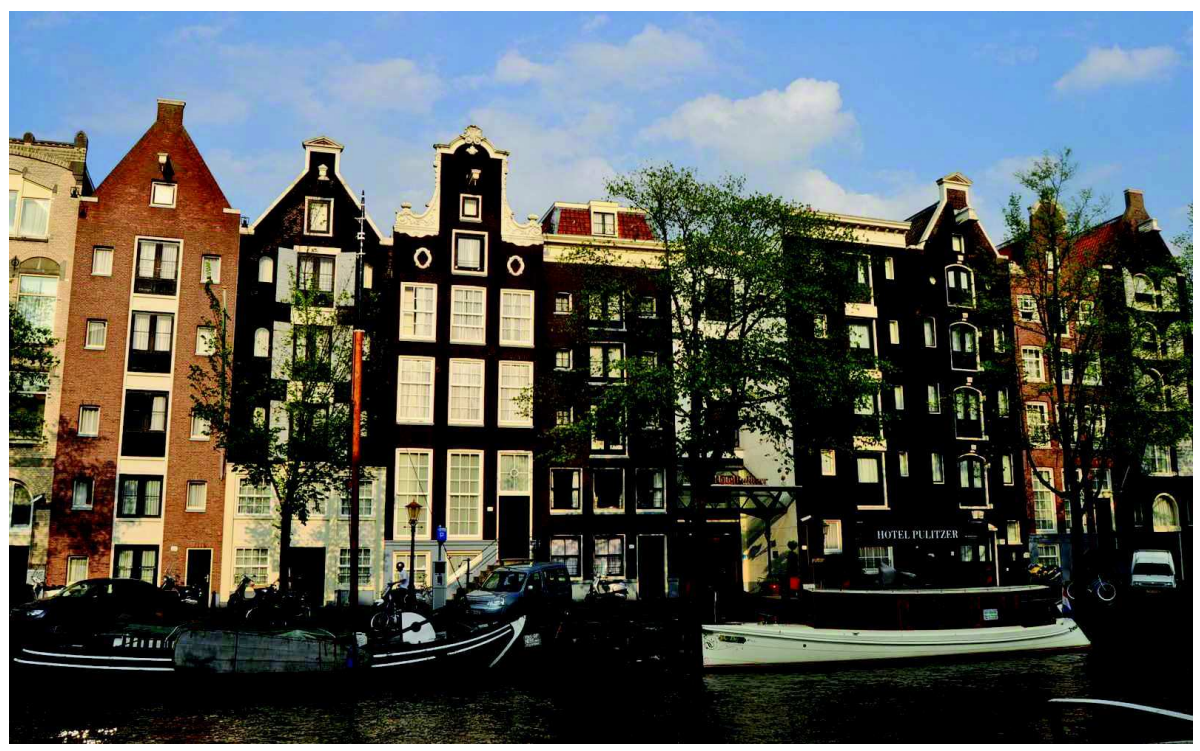

Figure 5.

Park Crescent at London by John Nash. Example of the principle of decorum.

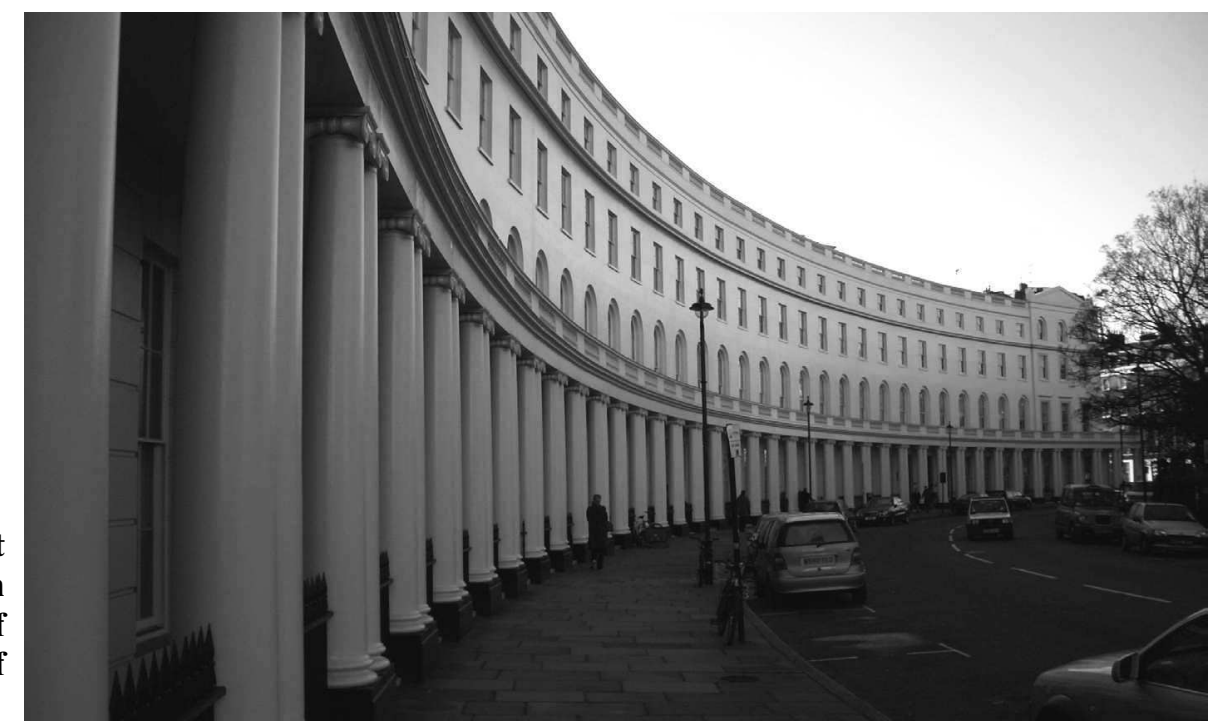

Figure 6.

View of Santorini, Greece. Example of the principle of identity.

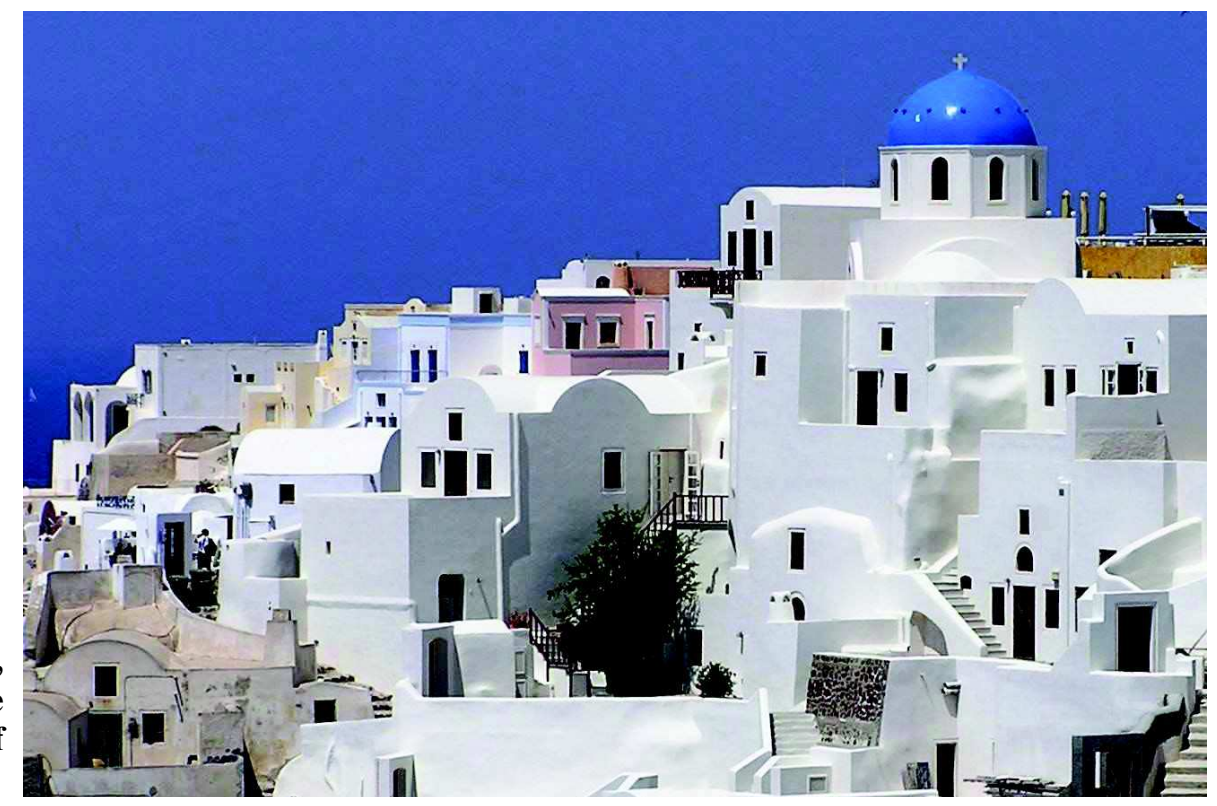


the relations of mathematical proportion and in some others it is simply connected to the inspiration of the taste alone.

Harmony with the natural environment

It is the right and pleasant way in which the city is integrated inside its natural environment.

Pertinent presence of nature inside the urban form Here we refer to parks, gardens, fountains, etc., that are qualified in diverse ways in the urban landscape.

\section{Chromatism for the well-being}

Its goal is the citizen's happiness. This is achieved thanks to the strong emotional value of colors.

\section{Virtuous sequence of spaces and forms}

The perception of the urban beauty is not only static, but also dynamic since the citizen moves through successive areas of the city.

\section{Virtuous essence}

The mere essence is not enough for beauty. There has to be some merit in that essence.

\section{Perceptual clearness}

It is what comes pristine and close to the senses. It also refers to sheer geometries and to the unmixed colours. This pure beauty was praised by plato.

\section{Happy clarity}

This concept does not only refer to the simple luminous clarity, but to the perceptual clarity stimulated by visual happiness.

\section{Rhythm and musicality}

They are qualities of fascination and dynamism of the form.

\section{Elaborated light}

The play of light and shade, the nuanced light, the nuanced shade, the creation of atmospheres, in the city at its different hours.

\section{Manifestation of life}

The communication of life through form is perceptually invigorating and transmits existential vigour, being a vehicle for beauty.
Valuable expressive power

It refers to cogency and to the intense and admirable communication.

\section{Serenity of form}

It is pleasant for the spirit, according to the taste of ancient greeks.

\section{Kind delicacy}

Delicacy and kindness are in themselves pleasant to the spirit.

\section{Qualified refinement}

It supposes the elaboration of the fine and the exquisite.

\section{Elegance}

Elegance in itself is always a vehicle of beauty.

\section{Humble charm}

It is another vehicle for beauty and it is characteristic of zen aesthetics.

\section{Wealth of form}

It supposes the abundance and qualified diversity of forms or the accurate presence of ornaments.

\section{Freedom and flexibility of form}

It makes the forms confident and meritorious.

\section{Graceful lightness}

It is a source of charm.

\section{The virtuous curve}

The curve has emotional repercussions and undoubtedly implies pleasure when it is virtuous.

\section{Qualified textures}

They are a source of interesting sensorial and psychological communication.

\section{Technical perfection in construction}

It conveys evidence of good realisation and the corresponding experiential satisfaction.

\section{Conclusion}

Our final goal in this work is to address the 
quality in urban form; not through superficial intuitive attitudes, but from conceptually structured intuitions based on shared quality experiences.

It is in this way that a new conceptual perspective of research is opened and offered to other researchers who are looking for achieving certain critical consensuses so needed today in order to face a bigger quality of form in the contemporary cities.

\section{References}

Alberti, L. B. (1991) De Re Ædificatoria (Akal, Madrid).

Alexander, C. (1980) A pattern language. Un lenguaje de patrones (Gustavo Gili, Barcelona).

Arnheim, R. (2001) La forma visual de la arquitectura (Gustavo Gili, Barcelona)

Benevolo, L. (1982) Diseño de la ciudad (Gustavo Gili, Barcelona).

Cullen, G. (2001) The concise townscape (Architectural Press, Oxford).

Gadamer, H.-G. (1997) Verdad y Método I (Sígueme, Salamanca).

Gombrich, E. H. (2004) Ideales e ídolos: Ensayos sobre los valores en la historia y el arte (Debate, Madrid).

Kruft, H.-W. (1994) A history of Architectural Theory. From Vitruvius to the present (Princeton Architectural Press, New York).

Lafuente Ferrari, E. (1985) La fundamentación y los problemas de la historia del arte (Instituto de España, Valencia).

Lynch, K. (1960) La imagen de la ciudad (Infinito, Buenos Aires).

Lynch, K. (1985) La buena forma de la ciudad (Gustavo Gili, Barcelona).

Moughtin, C. (2003) Urban Design. Street and Square (Architectural Press, Oxford).

Ortega y Gasset, J. (2012) Meditación de la técnica (Diálogo, Valencia)

Panofsky, E. (1987) El significado en las artes visuales (Alianza, Madrid).

Rasmussen, S. E. (2007) La experiencia de la arquitectura. Sobre la percepción de nuestro entorno (Reverté, Barcelona).

Rudofsky, B. (1973) Arquitectura sin arquitectos: Breve introducción a la arquitectura sin genealogía (Eudeba, Buenos Aires).

Ruskin, J. (1989) Las siete lámparas de la Arquitectura (CGCOAAT, Murcia).

Tatarkiewicz, W. (2007) Historia de seis ideas (Tecnos, Madrid).

Sitte, C. (1926) Construcción de ciudades según principios artísticos (Canosa, Barcelona).

Unwin, R. (1909) La práctica del urbanismo. Una introducción al arte de proyectar ciudades y barrios (Gustavo Gili, Barcelona). 